\title{
Conservation refugees
}

\section{and environmental dispossession}

\section{in 21 st century critical Geography}

\author{
Refugiados de la conservación y desposesión ambiental \\ en la Geografía crítica del siglo XXI
}

\author{
Scott William Hoefle \\ scotthoefle@acd.ufrj.br \\ Departament of Geography \\ Federal University of Rio de Janeiro (Brazil)
}

\begin{abstract}
This study explores the relevance of the concepts of conservation refugees and environmental dispossession for steering a middle course between unjust bio-centric conservation and antienvironmentalism of extreme right "populism". Historical geographers have recently taken up these concepts from contemporary Environmental History, and when with allied to the concepts of environmental ethics from Radical Ecology and Environmental Studies and nature enclosures from Political Ecology, a novel critique is produced of the role of full conservation units in debates surrounding global climate change. This kind of nature reserve is steeped in bio-centric environmental ethics which distill nature and dispossess native peoples and poor peasants. The latter are considered to be anthropic agents who are criminalized, removed and turned into conservation refugees in order to cleanse the landscape of (poor rural) human presence. Drawing on research undertaken on nature enclosures in three threatened biomes of Brazil, hybrid views of society-nature and actor-network assembly from Relational Geography are used to
\end{abstract}


interpret specific cases involving successful resistance to environmental dispossession in which local people forced a change in mentality of nature reserve administrators, turned foe into ally and built socially inclusive conservation strategies.

Palabras clave: conservation refugees; environmental dispossession; social ecological conservation; Brazil.

\section{Resumen}

Este estudio explora la relevancia de los conceptos de refugiados de la conservación y de la desposesión ambiental para adoptar una postura intermedia entre la conservación biocéntrica, cuyos efectos resultan injustos y el anti-ambientalismo que propone el populismo de la extrema derecha. La Geografía Histórica ha retomado recientemente estas nociones de la actual Historia Ambiental. Cuando ambos se conjugan con la ética ambiental de la Ecología Radical, los Estudios Ambientales y los recintos naturales de la Ecología Política se produce una nueva crítica del papel de las áreas protegidas en los debates alrededor del cambio climático global. Los espacios protegidos están impregnados de una ética ambiental biocéntrica que simplifica la naturaleza y despoja a los pueblos nativos y a los campesinos pobres. Estos últimos se convierten entonces en agentes antrópicos criminalizados y eliminados que devienen refugiados de la conservación para limpiar el paisaje de la presencia humana (rural y pobre). Este estudio se basa en la investigación realizada sobre recintos naturales en tres biomas amenazados de Brasil y utiliza las visiones híbridas del binomio sociedad-naturaleza y el ensamblaje de la red de actores de la Geografía Relacional para interpretar casos específicos. Estos son casos de resistencia exitosa a la desposesión ambiental en la que la gente local ha forzado un cambio en la mentalidad de los administradores de los espacios naturales protegidos, de modo que el enemigo se ha convertido en aliado y se han construido estrategias de conservación socialmente inclusivas.

Key words: refugiados de la conservación; desposesión ambiental; conservación socioecológica; Brasil.

\section{Introduction}

Key concepts and methods from Radical Environmental History and Studies, Political Ecology and Relational Geography perspectives are used to critically evaluate conservation policies based on bio-centric environmental ethics and urban bias which dispossess poor rural people. First, the 
disciplinary origin of the concepts of conservation refugees, environmental dispossession and nature enclosures are discussed with regard to Geography. Then, a relational approach of hybrid society-nature, actor-networks assembly and connectivity is used to understand how this form of environmental injustice can be overcome in specific cases in three critical Brazilian biomes in this key country for global conservation: 1) the Amazon Forest of the North, 2) the Pantanal wetlands of the Far West and 3) the Atlantic Forest of the eastern seaboard.

Four basic strategies for resisting environmental dispossession are identified in the Brazilian cases: 1) social movements agitate for permanence within conservation units, 2) local people force a change in the worldview of nature reserve officials, 3) low environmental impact activities, such as agro-ecological farming and community-based forestry, are promoted and 4) exclusive ethnic territories are created. We will see that these strategies can be pursued independently but the best chance for building less biased and more socially inclusive forms of environmental governance occurs when strategies are combined in such a way that two previously antagonistic actor-networks are reassembled into a new relationship of greater cooperation. This permits the development of wider partnerships with which to access extra-local resources and knowledge that are useful for deepening experiments in sustainable conservation. However, the key issue remains: are the positive cases merely exceptional or do they present lessons which can be applied elsewhere in order to combat conservationist bias against the rural poor in a more general way? The cases treated here present mixed results.

\section{Global conservation and nature enclosures: radical environmental history and critical political ecology enhanced with relational perspectives}

Radical Environmental History and Environmental Studies have their roots in the work of Cronin (1984, 1991), Crosby (1986), Merchant (1992), Pepper (1996) and Wilson (1991) and Critical Political Ecology in the work of Blaikie \& Brookfield (1988) in Geography, Wolf (1982) in Anthropology and Redclift (1987) in Sociology. Despite an earlier critique of Cronin (1991) made by political ecologists in a special issue of Antipode (Page \& Peet, 1994), in the first decades of the 21 st Century both perspectives became radicalized and converged in a global context of environmental backsliding, geopolitical wars over energy sources, violent counter-imperial movements and increasing social and regional inequality. 
Contemporary environmental historians castigate conservation icons such as Marsh, Yellowstone and the Grand Canyon for involving ethnic and class cleansing of the landscape. In the hundredyear conflict between Western conservation and native peoples and poor peasants the latter have been criminalized, dispossessed and turned into conservation refugees in order to produce pristine Nature to be visited in the comfort of a Land Rover by well-to-do urbanites from rich regions. Starting in colonial times and continuing into the present, bio-centric Western worldviews of an essentialized Nature without (rural) human presence have been imposed on the rest of the world in order to create distilled nature reserves free from anthropic action. Local populations were removed from their ancestral territories and their productive systems deformed (Adams \& Mulligan, 2009; Dowie, 2009; Jacoby, 2014/2001). This approach has recently been taken up by historical geographers and was subject to special sessions at the 2015 London International Conference of Historical Geographers, which resulted in the book Moral Ecologies (Griffin et al., 2019).

Environmental injustice also has its roots in a dualistic scientific worldview that arose in the late 19th Century in which researchers who study natural phenomena were radically separated from those who investigate human phenomena (Figure 1). On the bio-physical side of this divide, scientists use reductionist explanatory frameworks in which interaction between analyzed parts of one phenomenal level are thought to cause what is observed at the level immediately above it, stretching "up" from the interaction of sub-atomic particles at one extreme to astronomical phenomena at the other (Merchant, 2004; Simmons \& Cox, 1985). As a result, bio-physical researchers receive little or no training in the human and agronomic sciences and this completely distorts the attitude that they bring to conservation. Bio-physical scientists tend to hold a naïve view of an idealized nature which existed before humans on the planet, the remnants of which must be set aside and protected. This term refers to a grab bag of socio-environmental conditions including sprawling high-impact metropolitan areas and agricultural commodity landscapes as well as low-impact tribal and historical peasant land use in remote areas historically unsuitable for commodity production and hence less impacted. Consequently, park rangers and administrators with this worldview come to their work with a default negative attitude toward any human resident present in or near "nature areas". 
Figure 1. Secular reductionist science which separates nature from society

Theological Phenomena

\section{Astronomic Phenomena}

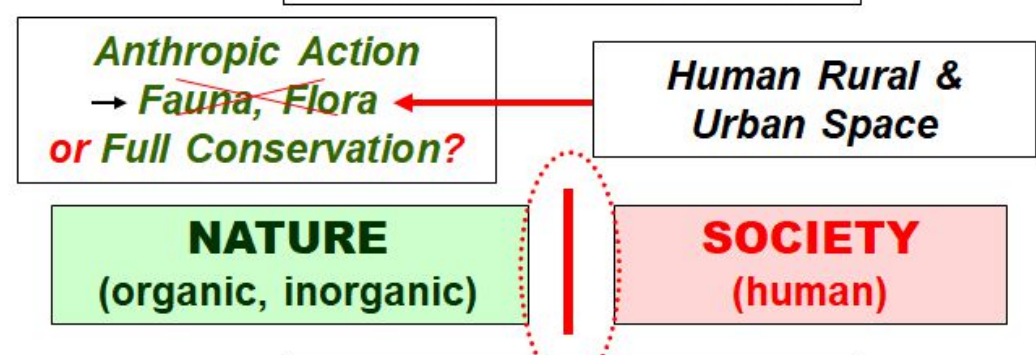

Sub-atomic Ṕhenomena
METAPHYSICAL DOMAIN

PHYSICAL DOMAIN

Macroscopic Universe
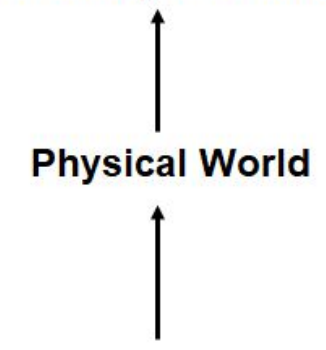

Microscopic Universe

Source: own elaboration

Against this view of rationalist science and bio-centric conservation, Radical Ecologists and Environmental Historians of the late $20^{\text {th }}$ Century developed a holistic view of science and conservation which mobilized disciplinary knowledge across phenomenal scales and in the case of deep ecology and spiritual ecology could even embrace a supernatural dimension inadmissible to secular materialism (Figure 2). Instead of separating nature from society, in the holistic view culture and environment are seen to be entangled entities and conservation needs to be decolonized. Instead of US-style national parks, European-style conservation/heritage units with sustainable human use are promoted. In the place of elitist bio-centric environmental ethics, homo-ecocentric environmental ethnics are advocated in order to attend to both human and ecosystem value and moral status (Merchant, 2004; Pepper, 1996). lan Simmons was a pioneer among geographers who seriously engaged this critical literature (Simmons, 1993; Simmons and Cox, 1985).

Political Ecology has a long history in Geography and over the years a number of geographers have made important contributions to this theoretical approach (Huber, 2017; Peet et al., 2011, Peet \& Watts, 1996/2004; Robbins, 2003; Zimmerer \& Bassett, 2003). With the growing importance of debates concerning environmental degradation, carbon emissions and global climate change, political ecologists increasingly criticize policies of mitigation of climate change based on carbon trade-offs. These green wash unsustainable agricultural, industrial and services 
activities and so occult the destructive nature of capitalism. Carbon colonialism places blame for rising global emissions on deforestation in the developing countries and not on industry and postindustrial life styles. This validates nature enclosures and green wars that are perpetrated against tribal peoples and poor peasants who resist leaving areas earmarked for conservation. Echoing Marx in Part 6 of Capital, in which he described enclosures in Highland Scotland resulting in poor grain farmers being thrown off the land in order to make way for deer hunting by English nobles, today metropolitan elites do this on a global scale in order to consume nature (cf. Büscher \& Fletcher, 2018; Forsythe, 2003; Hoefle, 2013; Hoefle \& Bicalho, 2016; Peet et al., 2011; Taylor, 2015).

Figure 2. Holistic science and social ecological conservation

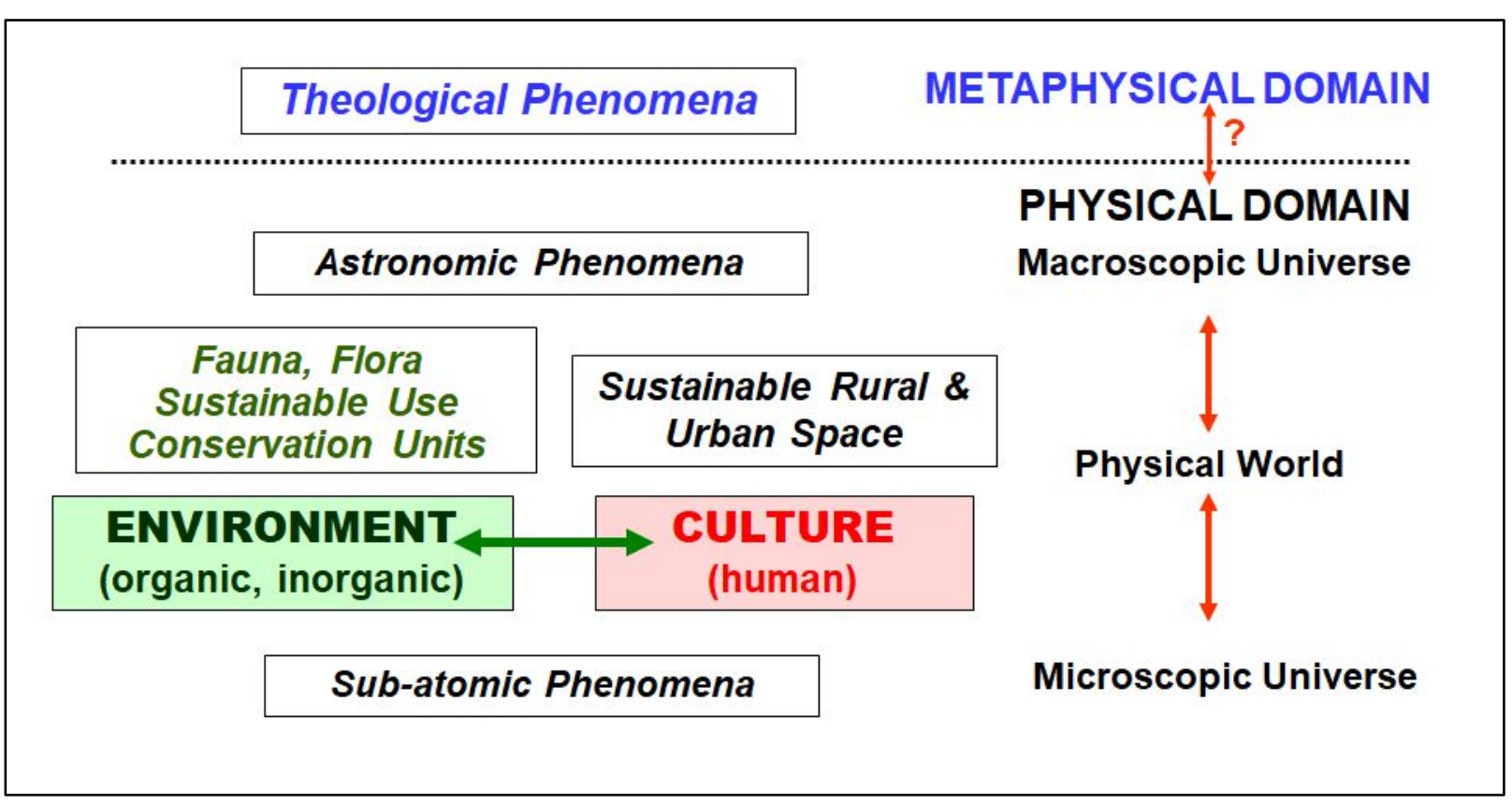

Source: own elaboration

Environmental policy that creates conservation refugees usually occurs in essentially rural areas and Kelly-Reif \& Wing (2016) argue that these areas almost exclusively foot the burden of environmental policy, which constitutes urban exploitation of rural people. No one ever suggests demolishing the buildings on Wall Street (New York City), in the City (London) or on Avenida Paulista (São Paulo) and planting a forest in their place because that would be "too expensive". Long ago Michael Lipton (1979) made a similar point when he criticized "urban bias" in development policy for favoring planning professionals and administrative personal that live in cities to the detriment of poor rural people. The difference today is that conservation policy causes this to happen. Class conflict becomes even more apparent when critical views of rural 
and eco-tourism are included in the evaluation of environmental policies. These leisure activities are often the only public use permitted by national park administrators and the main beneficiaries are urban middle- and upper-class individuals (Hoefle, 2016; Hoefle \& Bicalho, 2016).

Finally, these two approaches can be enhanced with $21^{\text {st }}$ Century relational perspectives in the social sciences, which go beyond just studying conflict over natural resources and propose an integrated view of natural and social networks composed of humans, animals, plants, landscapes and objects, all of which are considered to be actors in their own right (Descola, 2013; Holbraad \& Pederson, 2017; Latour, 2004, 2005; Whatmore, 2002). Karlsson (2018) goes so far as to call this perspective After Political Ecology, while Hodgetts (2018) and Schwanen (2017) show how relational connectivity-nexus perspectives embrace not only Political Ecology but also a number of other approaches in Human and Physical Geography. Consequently, actor-network theory (ANT) is incorporated as another dimension of the present study because this approach helps flesh out the details of homo-ecocentric environmental ethics and social ecology actornetworks used by poor rural folk to resist conventional bio-centric conservation.

\section{Methods for critically researching conservation}

The above theoretical framework is illustrated in results from long-term research in the Amazon rainforest, the Atlantic tropical forest and the Pantanal wetlands of Brazil (Figure 3). Over the last few decades in detailed field work undertaken at the farm- and community-level/site of enquiry, a pattern of biome-wide discrimination against poor rural folk emerged. Against this, some cases were identified in which poor farmers developed strategies for successfully resisting nature enclosures that might show the way forward.

In the cases treated research methods used involved direct interviews with productivist and non/post-productivist farmers $(n=158)$ as well as with community leaders $(n=32)$ concerning use of land and natural resources, environmental ethics \& perception, farming systems, labor regimes, market articulation, sources of monetary income, family structure, out-migration, access to public services and political mobilization. To correct for the often times too rosy pictures presented by community leaders the views of political rivals and common people were sought out. Interviews were also undertaken with representatives of the Brazilian Federal Environmental Protection Agency IBAMA (Instituto Brasileiro do Meio Ambiente e dos Recursos Naturais Renováveis), the Federal Parks Service ICMBio (Instituto Chico Mendes de Conservação da

Biodiversidade), the Federal Land Office INCRA (Instituto Nacional de Colonização e Reforma Agrária) and farm unions concerning agricultural and conservation policy, community 
development and partnership networks. Even if research methods reflected a political ecology perspective, the author is a radical empiricist, so that as a relational approach recommends, all pertinent social actors were researched and rival networks detected, usually one purely conservationist pitted against another fostering sustainable land use by local rural people, which in the cases presented here were eventually reassembled into wider social ecological networks. These are portrayed in Figures 4, 6 and 11, which were produced by confronting the specific views of the different social actors involved.

Figure 3. Research sites in three critical Brazilian biomes

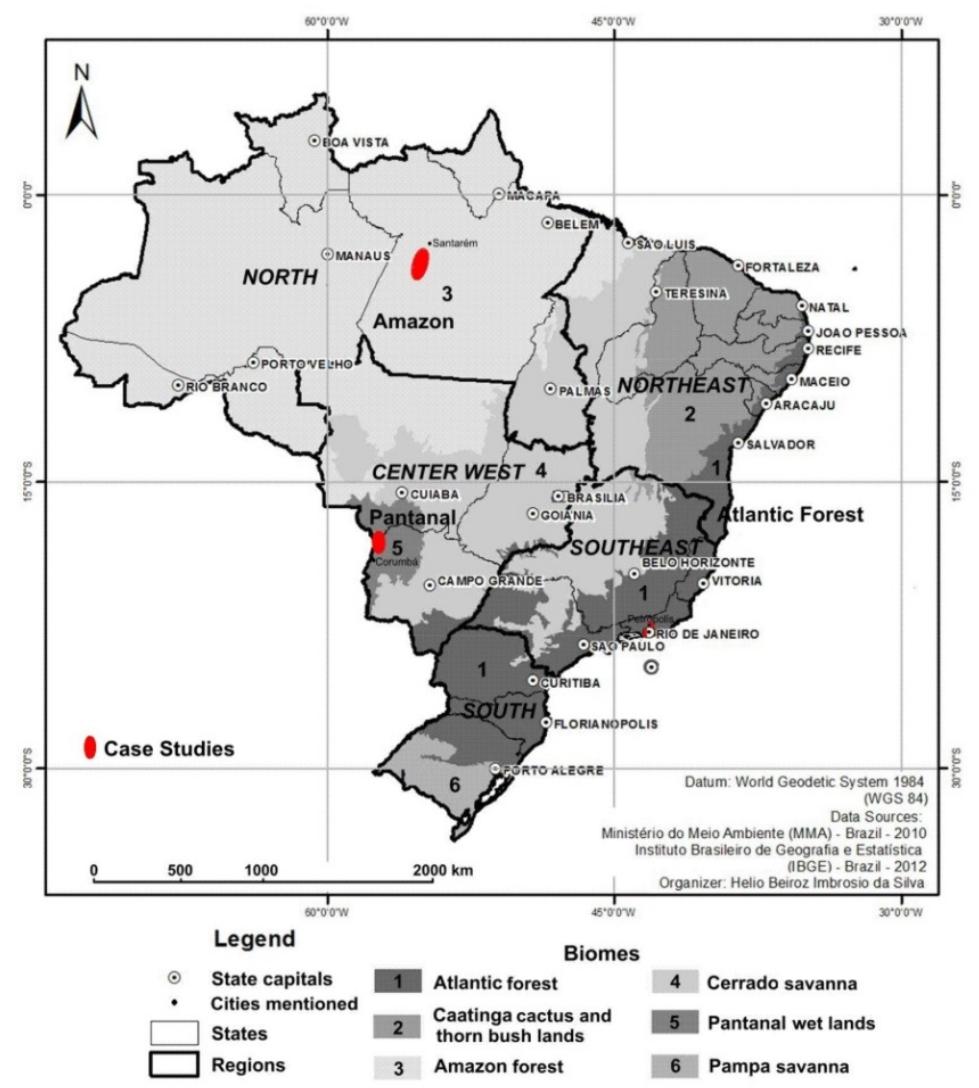

Source: multiple sources (see Figure)

\section{Resisting urban-rural exploitation in three critical Brazilian biomes}

During much of the $20^{\text {th }}$ Century conservation policy in Brazil mimicked the US model of national parks. Inspired by Yellowstone, the Brazilian Forest Code of 1934 enabled the creation of the first three full-preservation National Parks in a mountainous region of the Atlantic Forest biome located between Rio de Janeiro and São Paulo. In addition to these, a large conservation area already existed within the city of Rio de Janeiro since the 1860s. Ideally only nature tourism could be practiced within the limits of the parks but in fact some farmers who had been living in the area 
for centuries were allowed to stay. The Forest Code of 1965 in turn created new kinds of conservation of units: full-preservation Biological Reserves where only research can be undertaken and National Forests where economic use can occur. In the 1990s in a context of neo-liberalism, the federal government enacted legislation permitting Private Natural Reserves, which made class-based, urban-rural conflict even more explicit.

A sea change in policy occurred in 2000, when the National System of Conservation Units (SNUC) was implemented in Brazil, making an important distinction between full-preservation units on one side and on the other nature reserves with multiple sustainable uses. National Forests, Extractive Reserves, Sustainable Development Reserves and Indigenous Lands fall in this latter group, which allow low-impact land use and permit prior residents to stay, particularly if they are "traditional populations", such as Amerindians and historic peasants.

This shift in permitted land use did not occur because of enlightened attitudes of benign environmental policy makers but in reaction to successful multi-scale/site social movements mounted by rubber tapers, riverine peasants and Amerindians who forcibly maintained their presence in newly created conservation units and in the process turned some nature reserve officials from foe to partner. In the changed political context after the end of military rule in 1985, previously powerless political actors mobilized and built wider actor alliances. The first strategy of resisting dispossession drove the second strategy of changing conservationist mentalities and the two reassembled to undertake the third strategy of undertaking agro-ecological and agro-forestry land use systems. The fourth strategy of creating ethnic territories was also driven by Amerindian and Afro-Brazilian social movements which agitated for collective land rights under the jurisdiction of other ministries that imposed fewer bio-centric land use regulations.

However, the problem still remains in how to define "traditional population", which for most biologists means people who only pursue "subsistence production", two highly problematic social concepts. These categories were abandoned long ago by most social scientists, a fact which bio-physical scientists ignore. For the former, pure subsistence production does not exist for peasants because they have to produce a surplus above their alimentary needs in order to socially reproduce themselves. This is used to buy or barter items of first necessity which they do not produce as well as to meet other ceremonial and rent-taxation needs (Wolf, 1966, pp. 6-10). This problem drives the fourth strategy for resisting dispossession by creating ethnic territories which also prohibit predatory resource extraction and commodity production but not subject to the unrealistic restrictions imposed by environmental agencies. 


\subsection{Riverine peasants of the Amazon}

The Amazon region is considered to be a crucial environmental hotspot for preventing global climatic change. Ever since the planned colonization projects and massive road building programs of the 1970s, deforestation in northern Brazil has been roundly condemned because it causes loss of bio-diversity, interferes with precipitation patterns and river discharge, releases carbon dioxide through forest burning and by eliminating trees reduces the capacity for absorbing carbon (Davidson et. al., 2012). This in turn causes many environmentalists to consider frontier smallholders, ranchers and commodity producers in the Amazon to be enemies of the planet and of mankind (e.g. Butler, 2012; GCP, 2007). Sociological studies of this process also showed that colonization had a high human cost in the form of poverty, violent land dispute and accentuated social inequality (Foweracker, 1981; Hecht \& Cockburn, 1990; Oliveira, 1999; Schmink \& Wood, 1992).

With the promulgation of a new constitution in 1988 the Amazon became one of the world's great laboratories of socio-environmental experimentation. A host of global, national, regional, state-level, municipality-level and community-level actors interact in multi-scalar (or if a flat ontology reader prefers trans-local multiple-site) alliances surrounding regional and global environmental, developmental and ethnic issues. As a result, starting in the 1990s, many negative socio-environmental trends were gradually reversed as different levels of Brazilian government became more responsive and foreign GOs and NGOs financed a number of alternative development projects. The INCRA tried to defuse conflict on the advancing frontier by actively registering land. The IBAMA used remote sensing in real time to more effectively enforce deforestation laws and the ICMBio and environmental agencies in some Amazonian states shifted from bio-centric preservationism, which had no place for humans in conservation units, to sustainable land use governance embracing historic riverine peasants in National Forests, Rubber Tapping Reserves and Sustainable Development Reserves. Enormous areas were set aside as conservation units as well as Amerindian land. By 2013 about 25\% of the Amazon was encompassed by conservation areas and Amerindian lands and the goal was 30\% by 2020 (MMA, 2013a). Deforestation fell to a record low of 4,571 $\mathrm{km}^{2}$ annually by 2012 but then became creeping upward again and reached 7,900 $\mathrm{km}^{2}$ by 2018 (INPE/MMA cited by WWF, 2018). In 2019 a new right-wing federal government took office that was explicitly antienvironmentalist. Sensing impunity, gold prospectors, loggers and ranchers perpetrated largescale deforestation in the Amazon, which once again became a global issue. 
The community-forestry movement of the riverine peasants of the Tapajós National Forest (hereafter TNF) represents a middle course between bio-centric conservation and unfettered development of the Amazon. This movement is one of the most successful examples of resisting environmental dispossession in the Amazon and eventually became the bench mark for sustainable forestry in Brazilian National Forests and Extractive Reserves. However, the Tapajós movement had to overcome the initial bio-centric bias of the conservation administrators whose first action after the unit was set up in 1974 was to try to remove the long-resident population in order to distill nature.

Today the community forestry system is undertaken by the local rural population and not the commercial firms which first worked in the Tapajós National Forest because of a thirty-year struggle for rights in which strengthening collective goals produced the social capital necessary for later undertaking community-based forest management. The initial land dispute involved two rival actor-networks, one made up of the TNF, forestry researchers and logging firms on one side, and on the other side a network involving the local population, municipal governments and the INCRA (Figure 4). When the National Forest was first created in 1975 it overlapped with a few recently implemented INCRA settlements for frontier peasants who had arrived from other regions as well as with a string of eighteen historic peasant communities located along the Tapajós River.

The riverine population was made up of a historic peasantry with pronounced Amerindian ancestry who had a common social background of kinship and community ties. These people were better organized politically than the INCRA settlers and more active in pressuring for tenure rights. Their movement has its roots in the 1970s, when the Catholic Church induced community organization throughout the Amazon in an attempt to conciliate fishing and farming activities between neighbors as well as to pressure local government for public education and health services (Bicalho, 2009; Hoefle, 2000; Kadt, 1970). This community organization was fundamental for channeling land tenure resistance and political mobilization used to form alliances with the INCRA and municipal government against the federal forestry and environmental agencies. 


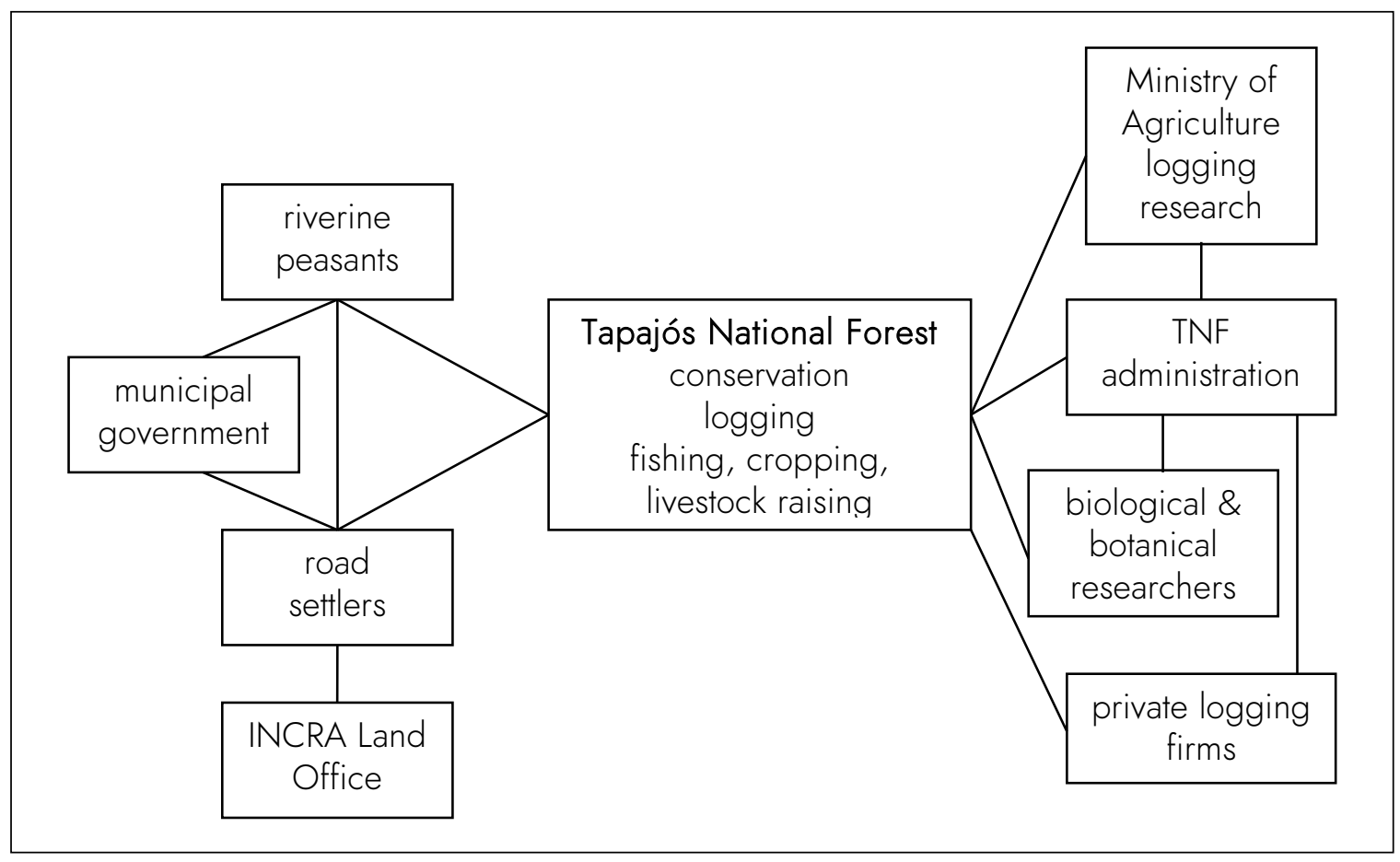

Source: field research $(2010,2013)$

The peasant movement adopted many of the dispossession resistance strategies that Jacoby (2014) identified for North America. In 1980 the riverine communities unilaterally set their land use area to ten kilometers inland from the river and in 1983 they paralyzed land survey work meant to remove them. In 1990 the TNF undertook an extensive inventory of forest resources which the peasants thought would lead to their eviction and they mobilized again. The Santarém county government came to their aid and in 1992 proposed to exclude the ten-kilometer area along the Tapajós River from the National Forest but the TNF administration rejected this. In 1996 a plebiscite was approved excluding the communities but the TNF did not abide by the result. In 2002 a land tenure commission was created to negotiate a concession within the National Forest which another plebiscite approved in 2003. In 2010 an agreement was finally signed conceding land use for twenty years but not permanent tenure or property rights (Figure 5). This was made possible because in the meantime the environmental agencies working in the Amazon had undergone a change of mentality and went from being an adversary to being an ally in sustainable development projects undertaken from 1996 onward. The first and second strategies of resisting dispossession enabled the third: developing agro-forestry activities.

Between 1997 and 2005 the community associations became formal legal entities of collective representation for negotiation with public institutions which enabled participation in alternative 
sustainable timber and non-timber forestry projects based on wider alliances with local, national and international governmental and non-governmental organizations. At the same time, three inter-community associations were set up to represent different groups of communities. The three then came together in the TNF-wide cooperative which became the vehicle for undertaking collective logging and other forestry projects as well as for providing technical training for members via projects with NGOs and the ICMBio (Figure 6).

Figure 5. Riverine communities within the Tapajós National Forest and sustainable land use zoning

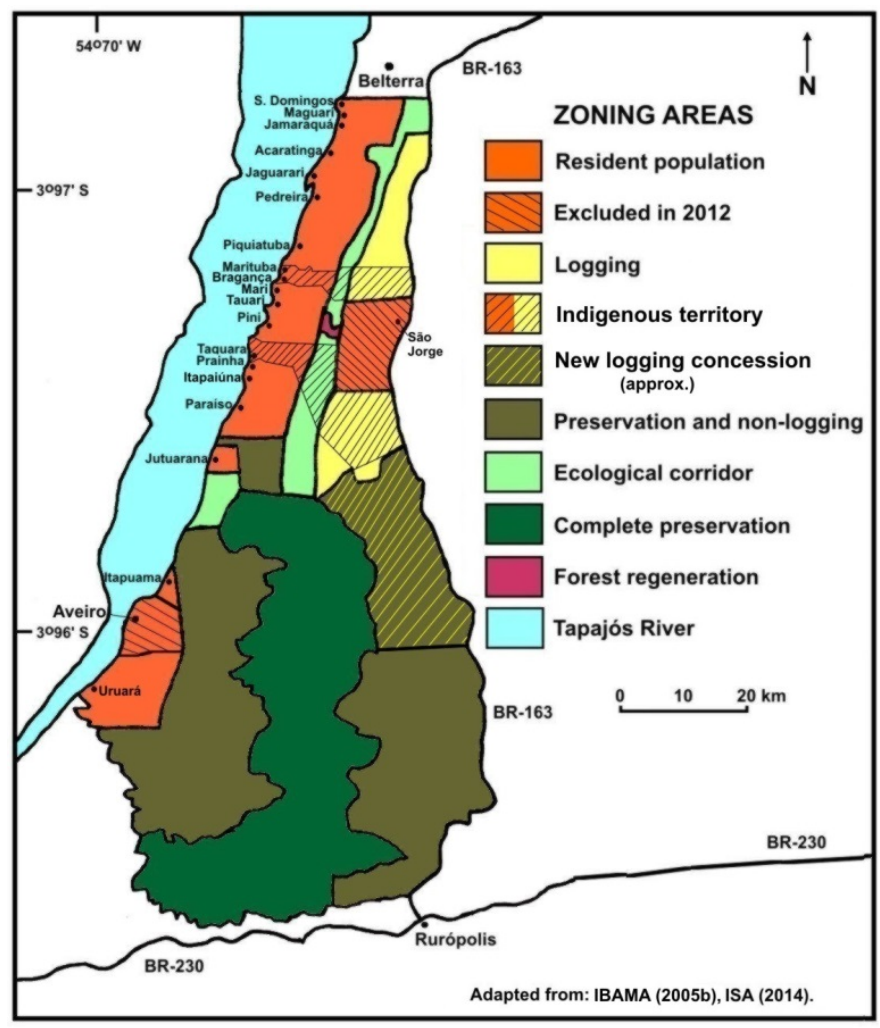

Source: adapted from IBAMA (2005); ISA (2014)

The NGOs favored non-timber activities, such as eco-tourism, tourist souvenir crafts, renewed latex tapping and the extraction of tree oils, but these generate little income. In 2013 income from these sources ranged from no income to US\$897 for interviewed families in total incomes of US\$13 to US\$11,217. The local people had undertaken many of the non-timber activities in the past but abandoned them as demand and prices fell over the $20^{\text {th }}$ Century. The coop was right to give priority to community timber production which generated an annual income of US $\$ 7,044$ to US\$13,655 for lumber jacks and other coop workers in 2013 (Figure 7). However, these workers only constitute $5 \%$ of the TNF resident population. Consequently, most people depend on 
meager government transfer payments and over time this has caused half of the young people to leave the TNF (Bicalho \& Hoefle, 2015).

Figure 6. Antagonistic actor-networks reassembled into a wider partner relationship

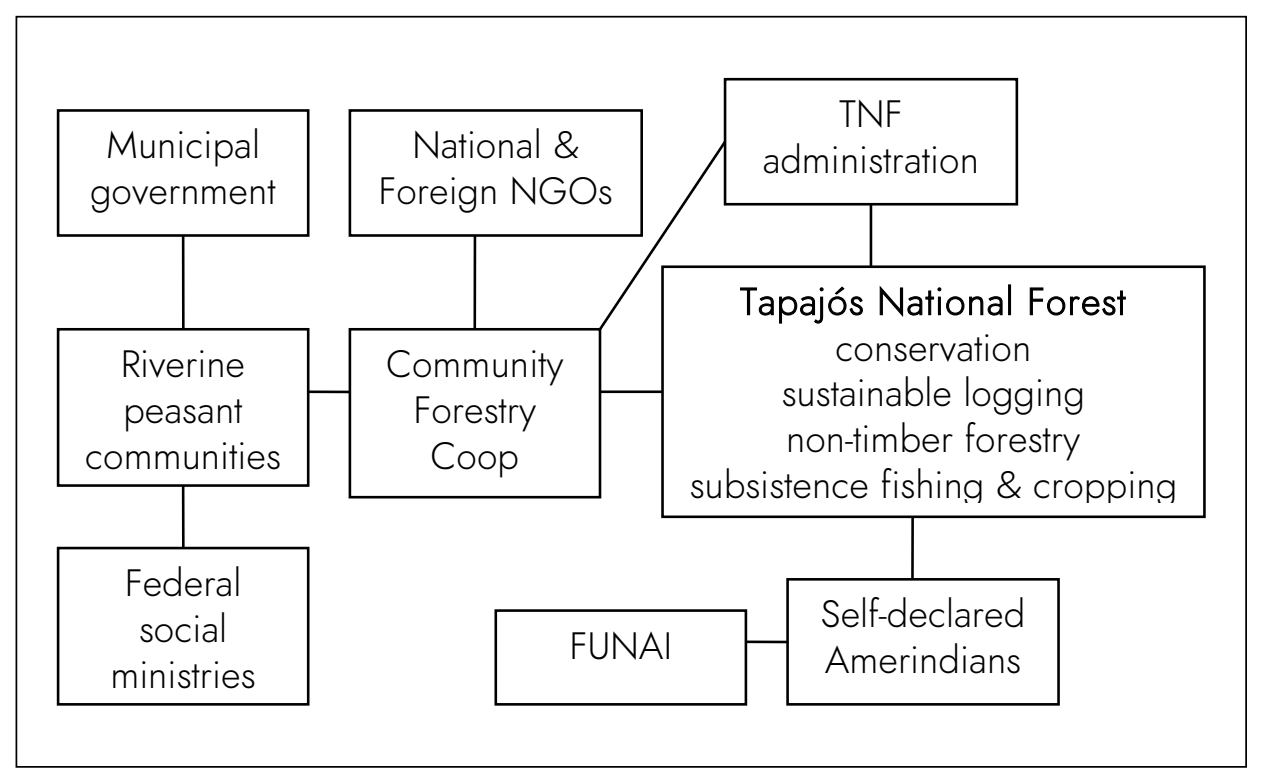

Source: field research $(2010,2013)$

Against the community-based forestry route to resisting environmental dispossession, another route emerged after 1988 when Brazilian ethnic-identity policy permitted taking a faster track to definitively gaining land via the fourth strategy of ethnic territories. This in turn threatened the political cohesion of the TNF-wide community movement which sustains the forestry activities. The Tapajós National Forest has three communities of Munduruku Amerindian descendants who migrated to the area in the past. Today they number about 500 individuals and live in Bragança, Marituba and Taquara villages located along the Tapajós River (ICMBio, 2014; Vaz Filho, 2011). As part of a highly successful region-wide political movement of native peoples of the Amazon, the three communities declared themselves to be Amerindians in order to receive indigenous lands. Under the jurisdiction of FUNAI the self-declared Amerindians gain access to potentially better schools and health services than those provided in the countryside by county governments. As Amerindians they also have guaranteed land rights and not a mere twenty-year concession which may or may not be renewed in the future. Most importantly, they are no longer subject to "subsistence" restrictions against raising cattle, selling fish and cropping more than one hectare of land in national forests. 
Figure 7. Lumber jack felling tree in community-based sustainable timber extraction

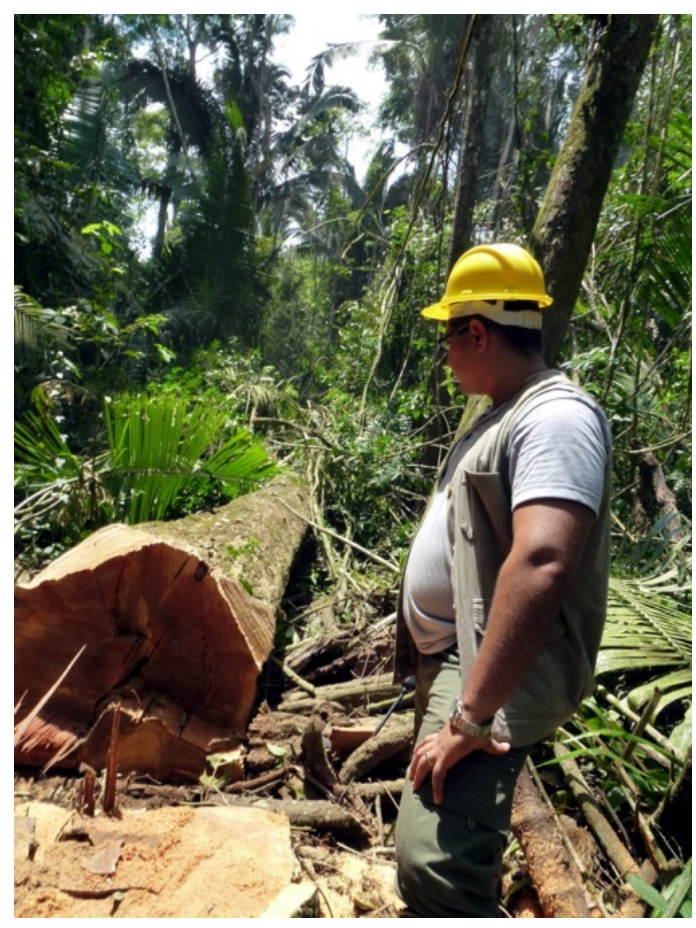

Source: field research (2013)

The problem with all of this is that the people of the other communities of the National Forest are physically and culturally indistinguishable from the self-defined Amerindians. Both groups have accentuated Amerindian biotypes, the same small-scale, slash-and-burn farming system based on manioc, fish and chicken-protein sources, identical wattle-and-daub or wooden houses, most people speak only Portuguese and share a spiritually-bifurcated Christian worldview laced with lore of enchanted spirits of Amerindian origin. However, in the case of indigenous territories only self-declared Amerindians can be present and the "non-indigenous" must leave and this causes conflict within communities and even within families.

One territorial strategy of the Amerindians represented a direct threat to the riverine peasants. In addition to the 10-km strip of land along the Tapajós that the peasants can use the Amerindians also claimed a large area located on the other side of the National Forest, exactly where the peasant cooperative developed its logging operations, under the allegation that the land was located in their ancestral hunting grounds. The ICMBio defused the issue by ceding another area further south and the coop agreed to train the self-defined Amerindians on how to undertake collective forestry.

Finally, it remains to be seen if the community-based forestry system developed in the Tapajós National Forest only was a success because of its close proximity to the important city of 
Santarém. With an urban population of over 215,000 inhabitants (IBGE, 2010), Santarém constitutes a sizeable market for rural products in a region where cities and few and far between. The city has an important port and is a hub for governmental and private-sector services. Timber products can be transported long distances to market but political synergy in remote communities may never gel, in which case the experience of the Tapajós National Forest would merely be an interesting experiment. This is reinforced by the difficulties faced by the newer national forests located further south along the BR-163, which have been systematically invaded by illegal loggers and ranchers. The latter over the years have played a cat-and-mouse game with the IBAMA and recently have been emboldened by the current anti-environmentalist federal government.

\subsection{Riverine peasants of the Pantanal}

The Pantanal of western Brazil is the largest wetlands complex in the world and is of such importance that the World Wildlife Fund considers it to be one its thirty-five global priority areas (WWF, 2016). The biome is spectacularly beautiful and presents exuberant flora and fauna which attract foreign and domestic tourists and in recent decades has been the object of conservation actions undertaken by GOs and NGOs (Figure 8).

\section{Figure 8. Pantanal wetlands}

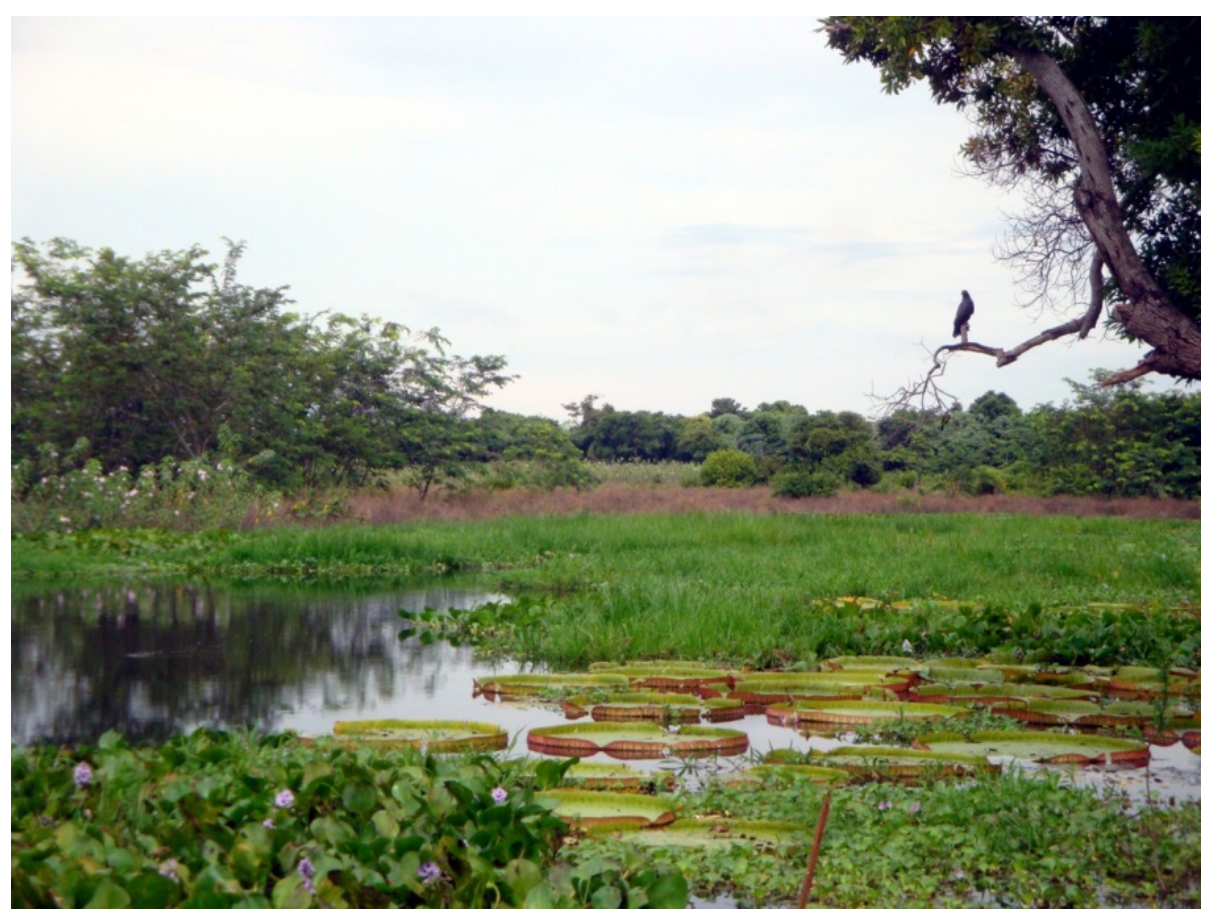

Source: field research (2015)

In 1981 an important federal national park for the Pantanal biome was set up in Mato Grosso state. Since then, enormous areas of land on the western and eastern banks of the Paraguay River 
on the Mato Grosso do Sul side of the state boundary have been purchased by wealthy investors of urban origin in order to set up hobby ranches, fishing camps or merely to engage in land speculation masquerading as private conservation units. They take advantage of neo-liberal conservation legislation introduced in the 1990s which encouraged the private sector to establish conservation units. An important mining corporation also bought land as a nature reserve to offset environmental degradation caused in other parts of the region. Public and private conservation reserves straddling the state line between Mato Grosso and Mato Grosso do Sul now occupy 276,087 hectares (Instituto Acaia, 2014; MMA, 2016) (Figure 9).

Figure 9. Conservation landscape of the Pantanal

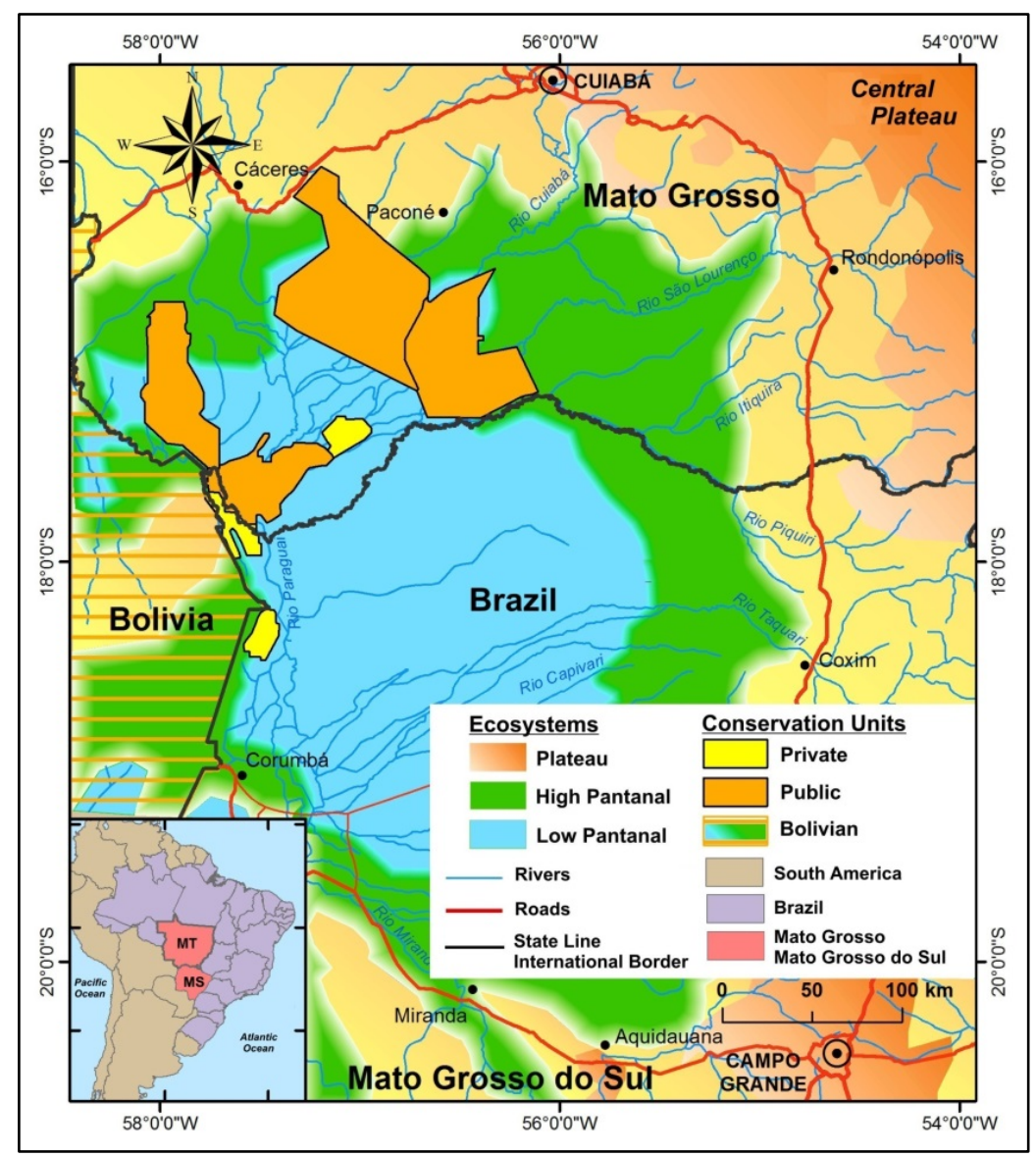

Source: adapted from MMA (2016)

Peasant fisher-farmers of the Paraguay River are descendants of Amerindians and settlers from other parts of Brazil, Bolivia and Paraguay who have lived in the wetlands for generations. During their lifetimes these people have always moved up and down the rivers of the Pantanal seeking work as ranch hands or when independent peasants following annual variation in fishing conditions and channel movements. 
As squatters the riverine peasants can potentially become involved in land ownership disputes and the new land owners have tried to remove them preemptively. First, the peasants were removed from the west bank of the Paraguay River forcing them to settle in squalid conditions on the east bank of the river (Figure 10). Then, land owners on that side of the river tried to remove them from there. This in turn provoked a class-action law suit between two rival actor-network assemblages, one involving public- and private-conservation units and another defending the rights of local peasant fishers (Figure 11).

Figure 10. Conservation refugee camps of the east bank of the Paraguay River

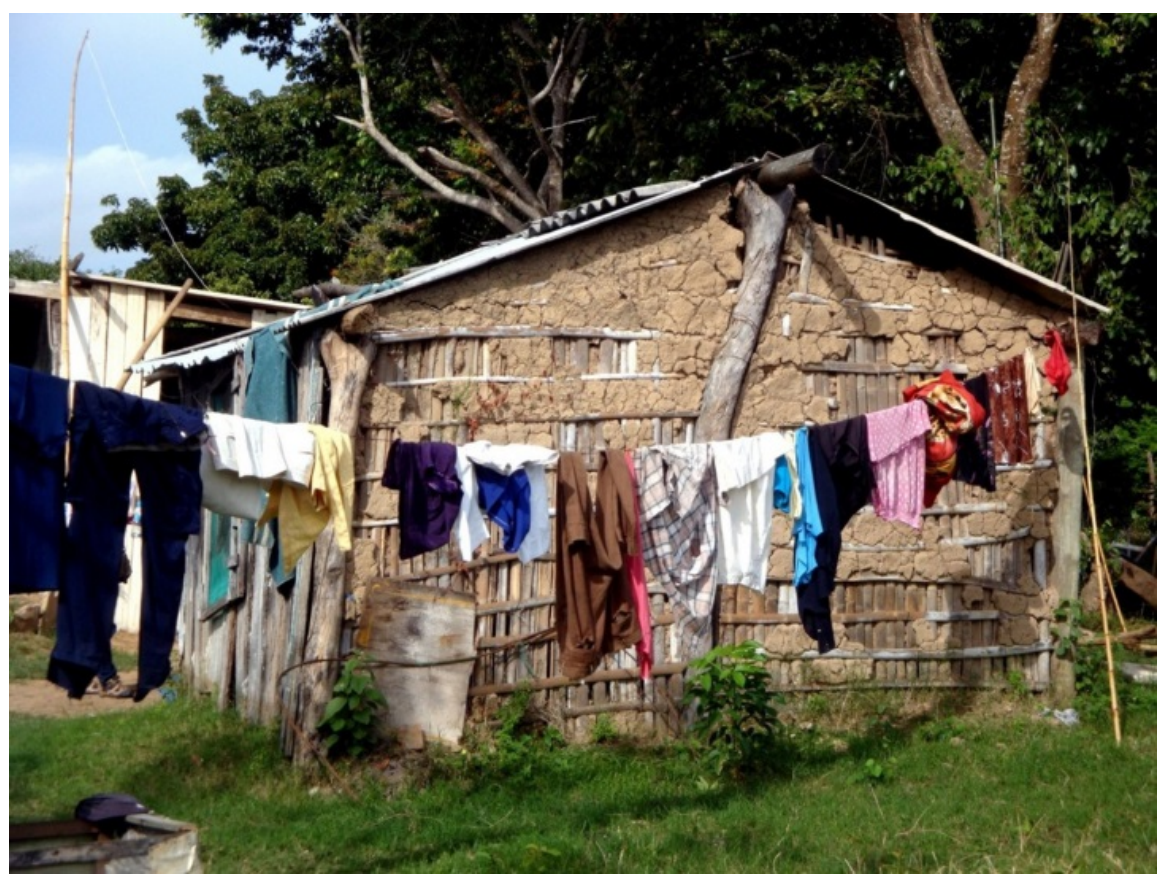

Source: field research (2015)

The attempts to evict the peasants are of dubious legality because according to Brazilian law the land up to fifteen meters in from the high water mark of the river is considered to be federal public domain and not private property. This became the legal basis for the class-action of the riverine peasants against the private-reserve owners, which was mounted with the help of the socially-conscious environmentalist NGO Ecologia e Ação (ECOA) and the sympathetic public defender's office of Corumbá. In May 2015, a Citizenship Expedition was mounted by the courts in which public hearings were held in the riverine communities along the Paraguay River, culminating in the final large hearing in Barra do São Lourenço community, located on the state divide between Mato Grosso and Mato Grosso do Sul. A Navy frigate transported participants representing the public defender's office, the courts, the Federal University of Mato Grosso do Sul and members of the press. 


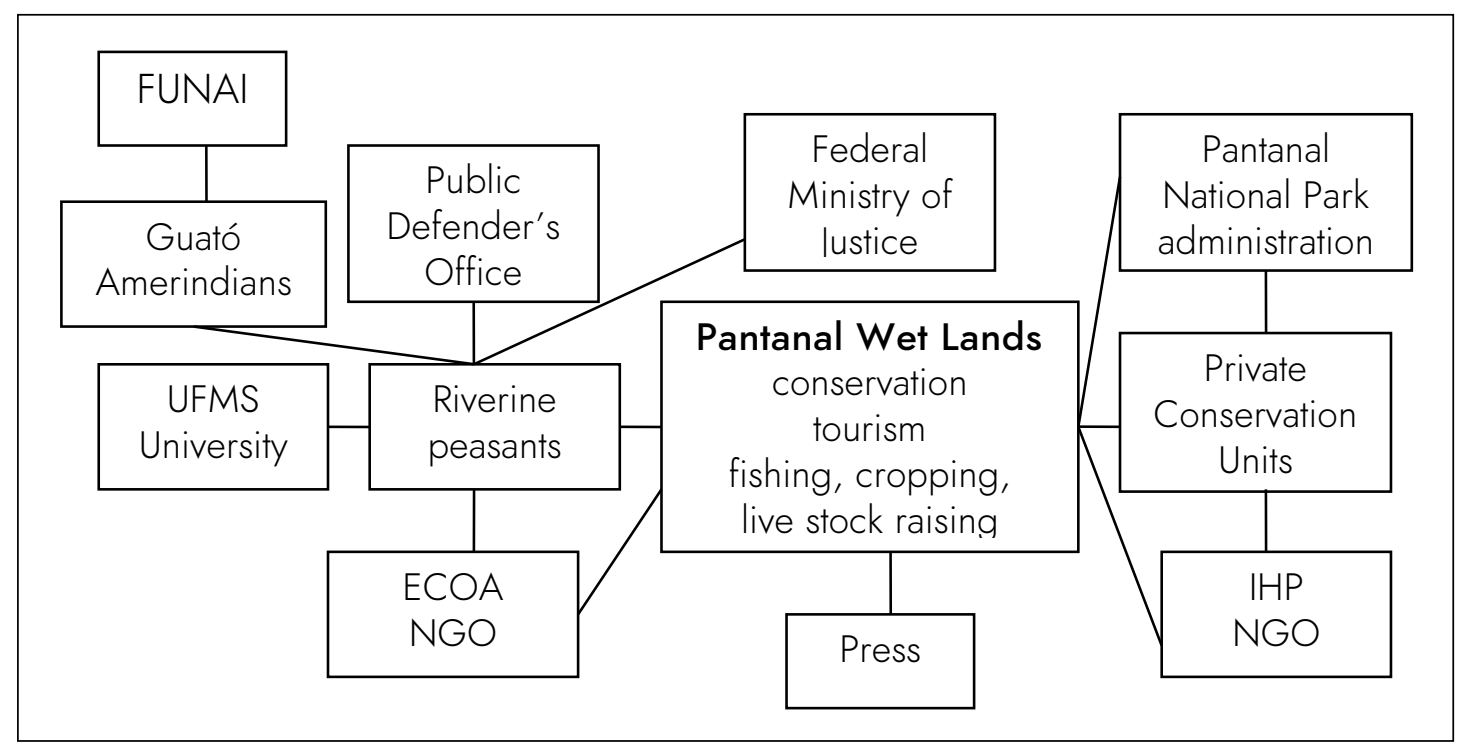

Source: field research (2015)

On one side, the private reserves were represented by the head of the Man of the Pantanal Institute (IHP). This NGO was established in Corumbá in 2002 and its stated purpose is preserving the Pantanal biome and local culture (IHP, 2016). The NGO head is a retired police coronal who led the fight against illegal alligator hunting in the 1980s so that the man has an honorable past in conservation action. The problem is the bio-centric emphasis of the NGO and his ideas concerning local culture which exclude the rural poor (OECO, 2008). The man appeared at the public hearing dressed in a camouflage military uniform, which he probably thought would intimidate the fishers.

The Pantanal National Park was also aligned with this side in the hearing because its representative considered the riverine population to be a menace. The Barra do São Lourenço community in particular was criticized for using its location at the junction of the Paraguay and São Lourenço Rivers to fish in the buffer areas of the National Park. The representative displayed a bio-centric attitude categorically stating that only those who fish strictly for "subsistence" should be permitted in the areas and not those who sell fish. As a biologist the man never received adequate training in the human sciences and is thus ignorant of peasant social reproduction. In fact, the 111 fisher-families present in the upper Paraguay River valley have an insignificant impact on fishing resources. They fished 93,462 kilos of fish in 2015 while the sports fishers took over 1,2 million kilos that year (Hoefle \& Bicalho, 2016). This difference challenges the default faith that nature reserve officials have in eco-tourism. The sport fishers are the real menace to conservation. They come from other regions and take home large amounts of prime frozen fish. 
The NGO ECOA was on the side of the local riverine population and has a history of working with the peasants in sustainable fishing practice and community development (ECOA, 2016). A number of university professors and their students from the Corumbá campus of the Federal University of Mato Grosso do Sul were also present at the meeting to lend their support to the local population and they along with members of the press outnumbered the local people at the meeting.

After hours of preparation the judge officially opened the hearing by removing her shoes, standing up with her bare feet on the dusty ground and giving an opening speech clearly in favor of the local people. The latter were portrayed as descendants of Amerindians, Brazilians, Bolivians and Paraguayans, who have suffered centuries of discrimination. Dismissing any pretence of impartiality, she signaled that the outcome against eviction was a foregone conclusion. Then each group present gave testimony and the clinching arguments were made by the highly mesticized Guató Amerindian "chief" and his Afro-Brazilian wife when they played the race card in the name of traditional land rights. In their testimony the two argued that because there are Amerindians mixed in the local population they should have the same rights to a territory which the Guató do in their indigenous lands to the north. Different from the Amazon case presented above, this case deals with the grievances of a relatively small local population against dispossession by rich outsiders so that maybe the drawbacks of this strategy mentioned above can be avoided.

\subsection{Mountain and urban farmers of the Atlantic Forest}

The South Atlantic Forest is the most threatened biome in the Brazil and a critical global hotspot for conservation. During much of Brazil's history commodity export production was undertaken on the coastal plains and inland valleys and plateaus of the Atlantic Forest and is where industrialization and urbanization took place after 1940. By 1990 only $8 \%$ to $9 \%$ of the biome still had forest cover. The latter was concentrated in the Coastal Mountains (the Serra do Mar in Portuguese) where the existence of steep slopes on the windward escarpment limited commodity farming in the past (Dean, 1996; Lino, 1992). This area had been relegated to poor farmers who practiced small-scale, medium-length fallow, slash-and-burn agriculture of food crops for selfprovisioning and root crops for the market.

The first Brazilian national parks and what became the Tijuca National Park in the city of Rio de Janeiro are located in the Coastal and Mantiqueira Mountains of central and southwest Rio de Janeiro state and adjacent parts of Minas Gerais and São Paulo states. The Tijuca National Park 
was created in 1961 but has a longer conservation history. Most of the 3,972 hectares that became the park were once deforested in the $19^{\text {th }}$ Century to extract timber for charcoal and construction materials as well as to experiment with commodity coffee production. When it became evident that this crop grew better in the valleys located behind the Coastal Mountains, starting in 1861 extensive reforestation was undertaken using slave labor with the aim of conserving water sources for the growing city of Rio de Janeiro (ICMBio, 2018). Today the Park and two other parks situated to the west of the city are covered by robust anthropogenic forest that constitutes the largest urban forest in the world but one which occults a dark past of social and environmental degradation (Oliveira et al., 2011). The Itatiaia National Park was the first official national park created in Brazil in 1937 with an area of 11,943 hectares that was expanded to 28,084 hectares in 1982 (ICMBio, 2013). The Serra dos Órgãos National Park also dates from 1937 when 11,034 hectares were set aside for a nature reserve and in 2008 was expanded by another 8,990 hectares (ICMBio, 2019).

Alarmed by the advanced state of deforestation of the Atlantic Forest in 1986 a group of concerned scientists, business people, journalists and environmental activists created the NGO SOS Mata Atlântica which lobbied federal and state governments for action to preserve remaining nature areas in the biome, particularly in the Coastal Mountains. This resulted in laws which banned felling and commercially exploiting primary Atlantic Forest as well as cutting regenerated secondary forest. Prominent Brazilian and transnational industrial and financial institutions are corporate sponsors (SOS Mata Atlântica, 2015). The mountains in the Southeast have long been a favorite place for weekend homes and nature tourism for urban elites of Rio de Janeiro and São Paulo so that the conservation efforts were also self-serving. Like what had occurred in the North American Atlantic Forest of the United States, the advanced stage of deforestation perhaps explains the emphasis on full conservation units but negative class perceptions of ignorant rural folk also reinforced bio-centric conservation (Hoefle, 2019).

The task of environmental conservation in the Atlantic Forest was also much easier than elsewhere in Brazil because after 1990 most commodity production had shifted to the Center-West region and mountainous areas of the Atlantic Forest had become agriculturally redundant. Existing conservation units were enlarged and a string of new ones were created to form an extensive ecological corridor spanning a number of states. Sloppy land surveying that defined the limits of new conservation areas by altitude curves resulted in parts of cities, rural tourism establishments and many farms being included within conservation units. The first two actors successfully resisted dispossession but extensive areas of land was seized from powerless poor farmers and never 
paid for (Figure 12). As a result, by the late 2000s forest had recovered to over $20 \%$ of the biome (Araujo et al., 2007; Hoefle, 2019).

Figure 12. A farm which lost half of its area when the Itatiaia National Park was enlarged in 1982

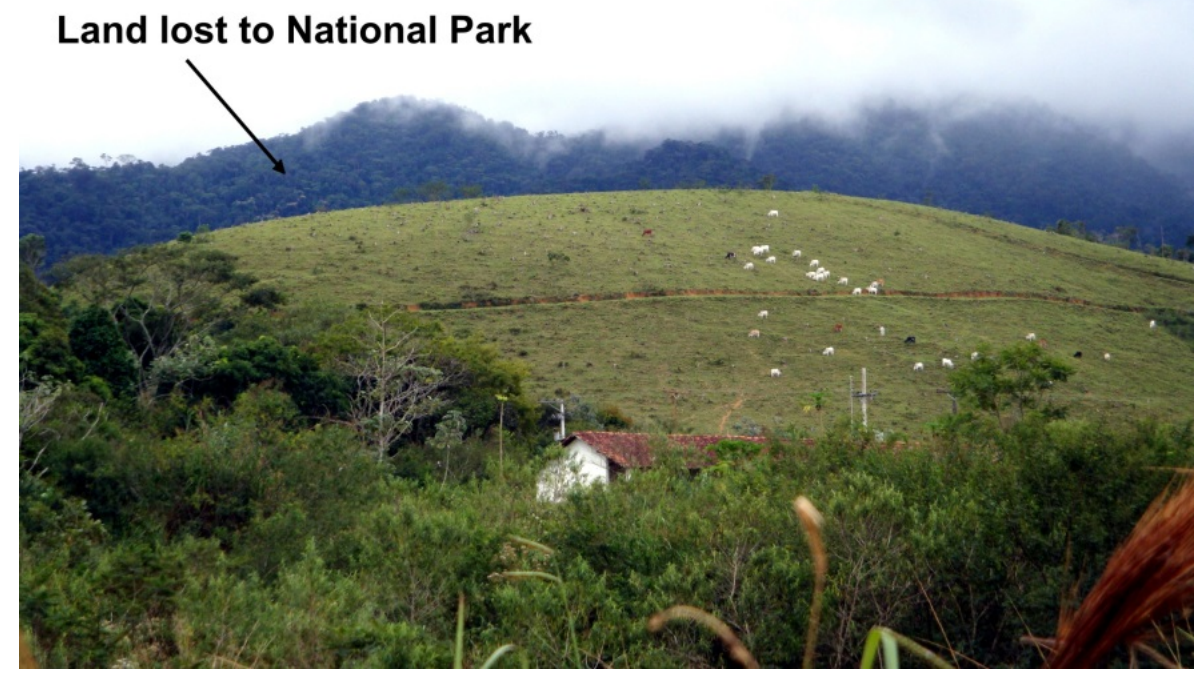

Source: field research (2011)

The Bonfim Valley of Petrópolis municipality is located just behind the Rio de Janeiro metropolitan area. In 2008 conflict with the local people arose there when the Serra dos Órgãos National Park was enlarged and incorporated the valley. Different from what occurred elsewhere in the Atlantic Forest, the local people successfully resisted dispossession and forced a change in mentality of the park administrators, resulting in the reassembly of two formerly antagonistic actor-networks into one social ecological assemblage.

At first, park administrators acted in default bio-centric mode and tried to remove the people without compensation based on the unjust logic that most did not have legal titles to the land. The upper part of the valley was originally a vacation ranch for the long-standing Brazilian president Getúlio Vargas (1930-1945, 1950-1952) but was abandoned after his death. Over a period of decades squatters occupied small plots on which they plant high-payoff vegetables for the metro Rio market using increasingly more intensive conventional farming practices, such as hydroponics in green houses. An alliance of local farmers and some ex-urbanites who lived in the valley arose to resist eviction. A compromise was eventually reached in which the farmers ceded their $20 \%$ 
mandatory forest reserve to the Park. This area was situated on the steep upper slopes of their land (Figure 13). An important park entrance was opened in the valley and local people were allowed to work as nature guides. Alternative employment was also created by a small eco-lodge situated near the park entrance.

\section{Figure 13. Territorial compromise in the Bonfim Valley}

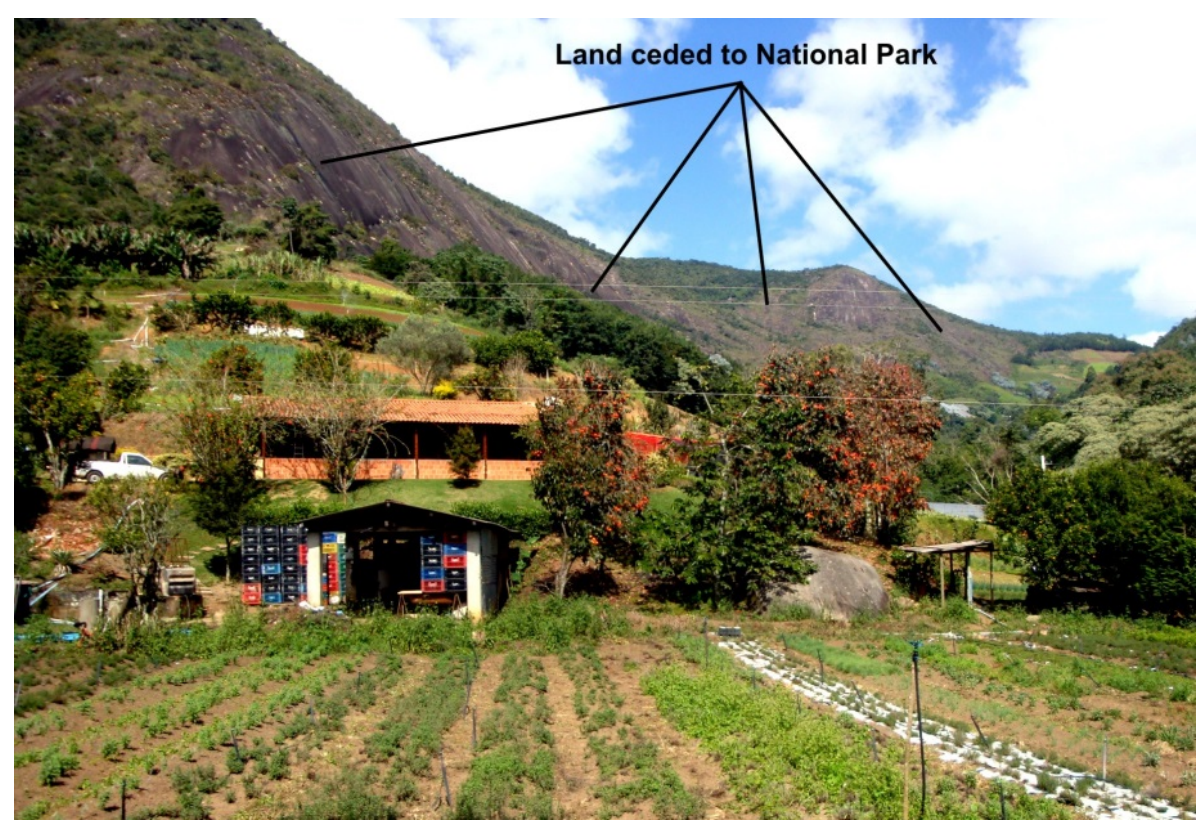

Source: field research (2017)

The case of urban farmers of the city of Rio de Janeiro highlights strategies for resisting dispossession when park officials refuse to change bio-centric mentalities. Cities are usually sprawling concrete and asphalted land covers that spew out alarming quantities of emissions, effluents and garbage. They rarely have large conservation units and the parks and gardens present do not constitute significant carbon sinks. However, Rio de Janeiro is different from other global metro areas because it is situated on the South Atlantic Ocean and urban space is partitioned by steep mountain ranges covered by forest today. Three major full conservation units exist in the city: the Tijuca National Park (described above), the Pedra Branca State Park (set up in 1974 with an area of 12,492 hectares) and the Mendanha Municipal Natural Park (set up in 2001 with 1,445 hectares) (INEA, 2012; Prefeitura Rio de Janeiro, 2019). The latter two parks are located in the western part of the municipality and as the city expanded over time it encompassed what was once the green belt of Rio de Janeiro (Bicalho, 1992; Musumeci, 1987) and turned peri-urban farmers into urban farmers. The latter were pressured by urban expansion on one side and the new conservation units on the other (Figure 14). 
Against these farmers, the rangers of the Pedra Branca State Park use the classic environmental policy of letting roads erode in order to make life difficult for the remaining rural population. No new electricity can be installed only that which existed when the park was created can be used. As a result, in the words of one administrator, "Lucky for us, the children do not want to stay". Luck has nothing to do with it, intentional policy makes farm life unattractive to the young in the expectation that they will leave.

Figure 14. The view from the Farmer's Union office (a) and remaining agriculture in and near the Pedra Branca State Park (b)
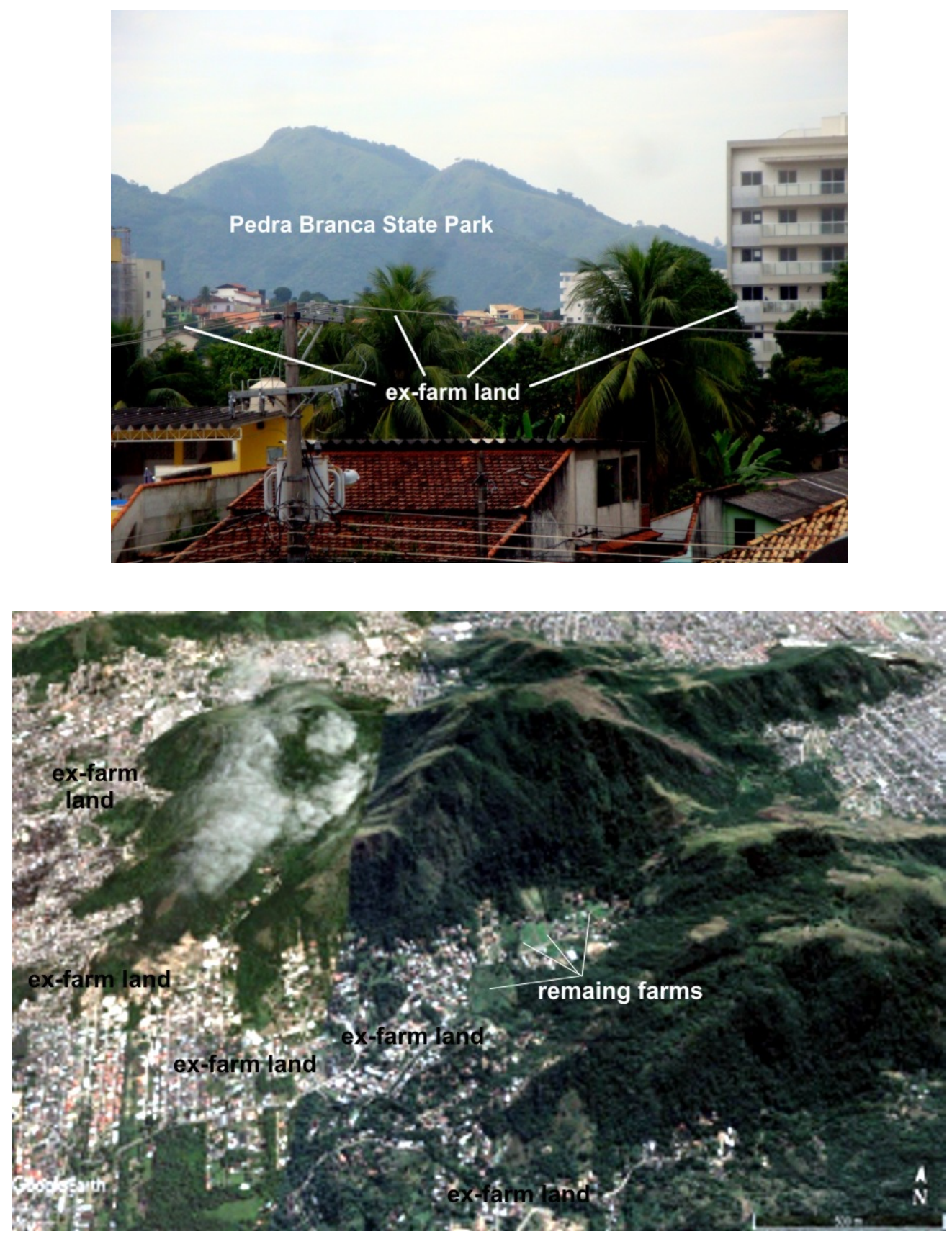

Source: field research (2018) (a); adapted from: GoogleEarthPro (2018) (b) 
An exception to this rule is when an important urban tourist has a weekend house in a park area. Road repair was permitted in the case of a high-ranking police official who has a weekend house at a road head and this benefited farms along the way. One of these farmers acidly observed, "If it had depended on us this never would have happened". Adding insult to injury, farmers and their representatives are outraged by the fact that roads and trails are built for urban tourists to use. Even motor cross events are held in the Park. It would appear that "anthropic action" only applies to poor rural populations and not to urban people.

Remaining farmers of the Pedra Branca State Park produce bananas and persimmon using agoecological methods which is legally permitted in sustainable conservation units but not in full conservation units so that this by itself is not a viable long-term solution unless the conservation unit is reclassified. Furthermore, these two crops do not generate much income and would require larger areas to be economically viable. Finally, due to poor road maintenance, farmers can only take their produce down from the park using mules and this limits production. The farmers are elderly and their children have left to work in other sectors so that this side of environmental policy looks suspiciously like a "final solution": wait for the old people to die off and no compensation needs to be paid.

The most common and successful of permanence strategies used by Rio farmers is to mount resistance movements. Urban farmers of Rio de Janeiro are becoming better organized and have mobilized their farm union to pressure state and municipal officials to attend to their needs. Foremost of their concerns is receiving relief from urban land taxes calculated in square meters instead of much lower rural taxes paid according to hectares of farmland. For this they must obtain legal status as farmers which in Brazil until recently was very difficult for urban farmers to receive. With this status they also qualify to sell to organic produce for school meals which pays premium prices. Over the last few years farmers and their political allies have held a number of meetings throughout the more rural areas of the city and were able to take advantage of new federal policy recognizing the importance of urban farming in Brazil.

Against these problems, some groups of farmers in the Pedra Branca and Mendanha parks have claimed to be of Afro-Brazilian ancestry. With this they can gain an ethnic territory and guarantee permanence on farmsteads occupied for generations. They also suffer less from environmental restrictions meant to make farming unviable because they come under the jurisdiction of federal social ministries and no longer state and municipal environmental agencies. These ministries 
promote agro-ecology and ethnic tourism which do not threaten conservation units in the same way that conventional agriculture does.

\section{Concepts and methods for critically evaluating bio-centric conservation}

The relevance of key concepts and methods from two $21^{\text {st }}$ Century approaches to environmental injustice were discussed and illustrated in cases involving discrimination against poor rural and urban farmers in Brazil. The concepts of conservation refugees, environmental dispossession and environmental ethics from Radical Environmental History and Studies were combined with the concepts of nature enclosures and rural-urban exploitation from Political Ecology to critically evaluate bio-centric conservation policy. The Political Ecology near equivalent of relational concepts and methods were also used to understand successful examples of resisting dispossession as well as the limitations to extending these strategies further afield.

One of the main differences between Political Ecology and Relational Geography has to do with the emphasis placed by the former on unequal power relations marginalizing poor people and putting them at greater risk to natural disasters and global climatic change (Peet et. al, 2011). As opposed to the flat ontology of Relational Geography (Marstan et al., 2005), Political Ecology also stresses how social inclusive green solutions have to work through, or at least around, the various scales/levels/sites of real-existing power in order to prevent vested interests at crucial levels of governance from boycotting bottom-up proposals initiated by local people (Hoefle, 2006; Paulson et al., 2003). It must be remembered that even Latour did not deny the importance of power, relative scale and social hierarchies if empiricist actor-network methods were respected and a priori assumptions were avoided concerning specific actors to be researched to the exclusion of others (2005, pp. 178, 183-184, 221-222, 260-261).

What emerges from the theoretical discussion and the empirical cases from Brazil is the fundamental need for administrators of conservation units to receive basic training in the human and agronomic sciences. All of the relatively successful cases presented here involved years, if not decades, of struggling against the default bio-centric prejudice of conservation officials. Few other localities in the biomes treated have the organizational capacity to do what is the equivalent of reinventing the wheel over and over and over again. The cases treated here would not be exceptional if officials were trained in a relational view of integrated social and natural assemblies, which would represent a huge step toward promoting homo-ecocentric environmental ethics and social ecological conservation (Figure 15). A social ecological view of conservation would create considerable opportunity for Geography as a discipline mediating the 
bio-physical and human sciences, but only if the discipline overcomes its own epistemological divide between human and physical specialty fields and becomes truly hybrid (cf. Cresswell, 2013; Whatmore, 2002).

\section{Figure 15. What social ecological conservation would look like in mountainous areas of the Brazilian Atlantic Forest}

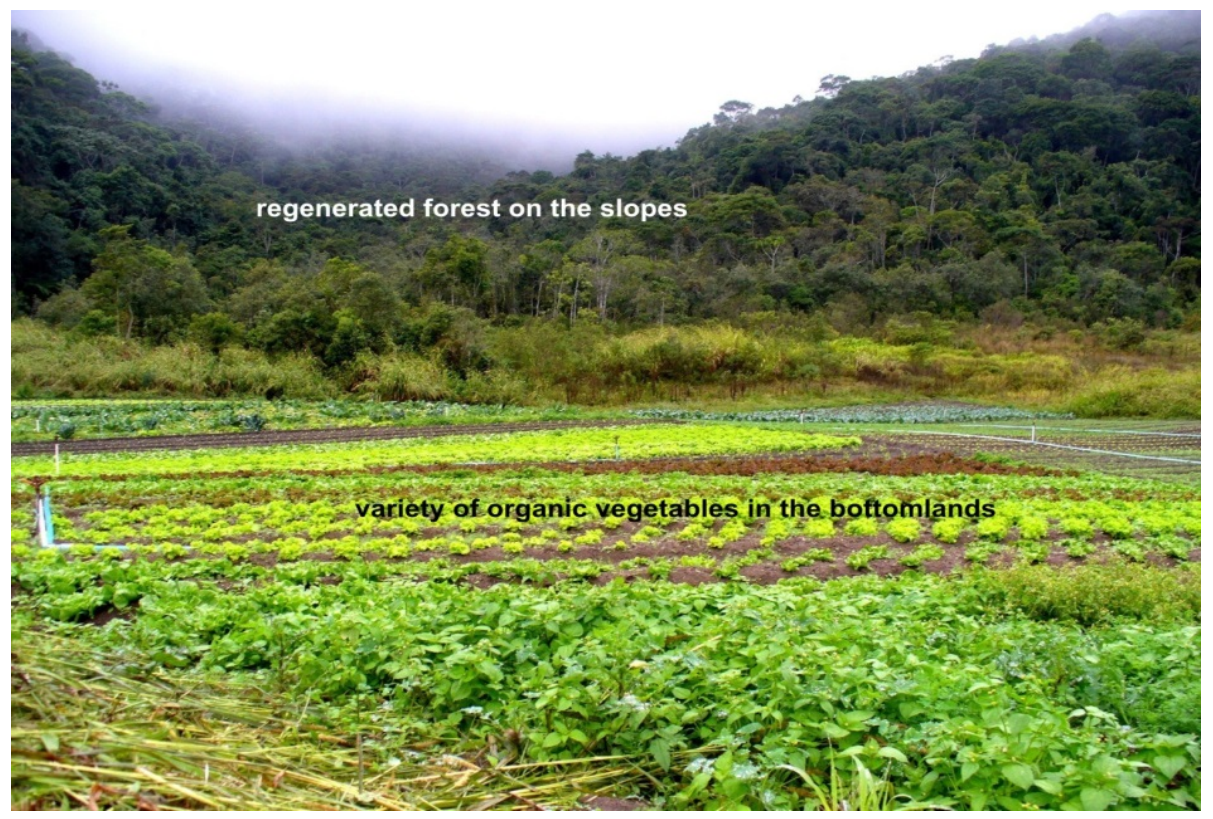

Source: field research (2008)

The radically different resulting social landscapes of full conservation as opposed to sustainable social ecological conservation could not be starker. Rickard (2007) contrasted the US model of conservation units as exemplified by Yellowstone and the Grand Canyon, which excludes people from living within but are ringed by gaudy tourist development consisting of motor lodges, souvenir shops and fast food establishments located just outside the park limits to the European model of sustainable regions, which include both nature reserves and sustainable human land use within the same greater zoning units.

The rise of the second conservation model in environmentally important countries like Brazil in the 1990s depended on an exceptionally favorable alignment of political agendas of local, state/provincial, regional, national and international socio-environmental actors. This political alignment has been jarred by the increasingly rightward shift in global politics, which have become pointedly nationalist, authoritarian, culturally conservative, xenophobic and antienvironmentalist. 
In 2019 the new right-wing Brazilian president refused to host the scheduled UN Climate Change Summit in Brazil and boycotted the UN Climate Action Summit in New York. Then at the annual opening of the General Assembly he announced a freeze on new conservation units and ethnic territories of the type that lay at the heart of the strategies for resisting urban and agribusiness encroachment as well as environmental dispossession highlighted here. This kind of antienvironmentalism is meant to favor his electorate of agribusiness and mining interests and not native peoples, historic peasantries or nature areas. However, this electorate is increasingly alarmed by the threats of the European Union and consortiums of private corporations to boycott their export commodities. Nevertheless, it must be pointed out that the bulk of Brazilian exports now go to the Middle East and East Asia where most political leaders could care less about environmental preservation, elective politics, social justice and have effectively decoupled economic development from liberal democracy (cf. Harvey, 2010, p. 199). Consequently, new strategies for resisting dispossession will have to come from social movements within Brazil and not wait for the EU to pressure agribusiness to pressure politicians. The best that can be expected from the current Brazilian authorities is more environmental denial, inaction and fake news.

Acknowledgements: Research funded by the Conselho Nacional de Desenvolvimento Científico e Tecnológico (CNPq - Brazil) and the Fundação Carlos Chagas Filho de Amparo à Pesquisa do Estado do Rio de Janeiro (FAPERJ - Brazil). The author would also like to thank the help of the researchers Ana Maria Bicalho, Ana Paula Araújo and Icléia Vargas Albuquerque as well as that of student assistants in fieldwork undertaken over the years.

Authorship statement: The author declares no conflict of interest. 


\section{References}

Adams, W.M., \& Mulligan, M. (2003). Introduction. In W.M. Adams \& M. Mulligan (Eds.), Decolonizing nature: strategies for conservation in a post-colonial era (pp. 1-15). London: Earthscan.

Araujo, M.H.S., Cruz, C.B.M., \& Vicens, R.S. (2007). Levantamento da cobertura vegetal nativa do bioma Mata Atlântica. Rio de Janeiro: Instituto de Estudos Socioambientais do Sul da Bahia.

Bicalho, A.M. (1992). Agricultura e ambiente no município do Rio de Janeiro. In M.A. Abreu (Ed.), Natureza e sociedade no Rio de Janeiro (pp. 285-316). Rio de Janeiro: Prefeitura da Cidade do Rio de Janeiro.

Bicalho, S.M (2009). Steps toward enhancing social capital in the Amazon. In D. C. Wood (Ed.), Climate change, culture, and economics. anthropological investigations (pp. 67-105). Bradford: Emerald Scientific.

Blaikie, P., \& Brookfield, H. (1986). Land degradation and society. London: Metheun.

Büscher, B., \& Fletcher, R. (2018). Under pressure: conceptualising political ecologies of green wars. Conservation and Society, 18(2), 1-9. www.doi.org/10.4103/cs.cs_18_1

Butler, R. (2012). Threats to rainforests from humankind. https://rainforests.mongabay.com/0803.htm

Cresswell, T. (2013). Geographical thought. Chichester: Wiley Blackwell.

Cronin, W. (1983). Changes in the land. Indians, colonists, and the ecology of New England. New York: Hill \& Wang.

Cronin, W. (1991). Nature's metropolis. New York: Norton.

Crosby, A.W. (1986). Ecological imperialism. Cambridge: Cambridge University Press.

Davidson, E., Araújo, A., Artaxo, P., Balch, J., Brown, I., Bustamante, M., Coe, M., ... Wofsy, S. (2012). The Amazon basin in transition. Nature, 481, 321328. www. doi.org/10.1016/i.cub.2016.08.049

Dean, W. (1995). With broadaxe and firebrand: the destruction of the Brazilian Atlantic Forest. Berkeley: Univ. of California Press.

Descola, P. (2013) [2005]. Beyond nature and culture. Chicago: Chicago Univ. Press. 
Dowie, M. (2009). Conservation refugees: the hundred-year conflict between global conservation and native peoples. Cambridge, MS: MIT Press.

Forsyth, T. (2003). Critical political ecology: the politics of environmental science. Milton Park: Routledge.

ECOA (2016). Quem somos. Retrieved from www.riosvivos.org.br/institucional-2/ecoa

Foweraker, J. (1981). The struggle for land. Cambridge: Cambridge Univ. Press.

GCP (Global Carbon Project) (2007). GCP - carbon budget. Retrieved from www.globalcarbonproject.org/carbonbudget/07/index.htm

Griffin, C., Jones, R., \& Robertson, I. (Eds.). (2019). Moral ecologies. histories of conservation, dispossession and resistance. London: Palgrave-Macmillian.

Harvey, D. (2010). The enigma of capital. Oxford: Oxford Univ. Press.

Hecht, S.B., \& Cockburn, A. (1990). The fate of the forest. developers, destroyers, and defenders of the Amazon. Chicago: University of Chicago Press.

Hodgetts, T. (2018). Connectivity as a multiple: in, with and as 'nature'. Area, 50, 8390. www.doi.org/10.1111/area. 12353

Hoefle, S.W. (2000). Patronage and empowerment in the central Amazon. Bulletin of Latin American Research, 19, 479-499. www.doi.org/10.1111/j.1470-9856.2000.tb00120.x

Hoefle, S.W. (2006). Eliminating scale and killing the goose that laid the golden egg? Transactions of the Institute of British Geographers, 31, 238-243. www.doi.org/10.1111/j.1475$\underline{5661.2006 .00203 . x}$

Hoefle, S.W. (2013). Beyond carbon colonialism: frontier peasant livelihoods, spatial mobility and deforestation in the Brazilian Amazon. Critique of Anthropology 33(3), 193213. www.doi.org/10.1177/0308275X13478224

Hoefle, S.W. (2016). Multi-functionality, juxtaposition and conflict in the central Amazon: will tourism contribute to rural livelihoods and save the rainforest? Journal of Rural Studies, 44, 2436. www.doi.org/10.1016/j.jrurstud.2015.12.009

Hoefle, S.W. (2019). Ghosts in the forest: the moral ecology of environmental governance toward poor farmers of the Brazilian and US Atlantic Forests. In C. Griffon, R. Jones \& I. Robertson (Eds.), Moral ecologies. histories of conservation, dispossession and resistance (pp. 99-125). Basingstoke: Palgrave Macmillan. 
Hoefle, S.W. \& Bicalho, A.M.S.M.. (2016). Nature enclosures: historic peasants versus public and private conservation units of the Paraguay River in the Pantanal wetlands of western Brazil. Belgeo, 4, 1-18. doi.org/10.4000/belgeo. 19677.

Holbraad, M., \& Pedersen, M.A. (2017). The ontological turn. an anthropological exposition. Cambridge: Cambridge University Press.

Huber, M.T. (2017). Industrializing political ecology. Annals of the American Association of Geographers, 107, 151-166. www.doi.org/10.1080/24694452.2016.1219249

IBAMA (Instituto Brasileiro do Meio Ambiente e dos Recursos Naturais Renováveis) (2005). Plano de manejo: Floresta Nacional do Tapajós. Brasilia.

IBGE (Instituto Brasileiro de Geografia e Estatística) (2010). Santarém. Retrieved from www.cidades.ibge.gov.br

ICMBio (Instituto Chico Mendes de Conservação da Biodiversidade) (2018). História. Retrieved from www.parquedatijuca.com.br/historia.php

ICMBio (2013). Aspectos Gerais do Parna Itatiaia. Retrieved from www.icmbio.gov.br/ parnaitatiaia/images/stories/Normas_UP/Aspectos_Gerais.pdf

ICMBio (2014). Floresta Nacional do Tapajos. Retrieved from www.icmbio.gov.br/\%20 flonatapajos

ICMBio (2019). Parna Serra dos Órgãos: História, Gestão e Manejo. Retrieved from www.icmbio.gov.br/parnaserradosorgaos/o-que-fazemos/gestao-e-manejo.html

IHP (Instituto Homem Pantaneiro). (2016). Histórico. Retrieved from www.ihp.org.br/ ?conteudo=canal\&canal_id=9

INEA (Instituo Estadual do Ambiente). (2019). Parque Estadual da Pedra Branca. Retrieved from www.inea.rj.gov.br/Portal/Agendas/BIODIVERSIDADEEAREASPROTEGIDAS/Unidadesde

\section{Conservacao/INEA_008594}

Instituto Acaia (2014). Serra do Amolar. Retrieved from www.acaia.org.br/wpcontent/uploads/2007/07/RPCSA_2014_Apres_v2.pdf

ISA (Instituto Socioambiental) (2014). Território indígena Bragança/Manituba and Território Indígena Mundukuru/Taquara. Retrieved from www.ti.socioambiental.org/pt-br/terrasindígenas\%20/4178/4176 
Jacoby, K. (2014) [2001]. Crimes against nature: squatters, poachers, thieves. Berkeley: University of California Press.

Kadt, E. (1970). Catholic radicals in Brazil. London: Oxford University Press.

Karlsson, B.G. (2018). After Political Ecology. Anthropology Today, 34, 2224. www.doi.org/10.1111/1467-8322.12422

Kelly-Reif, K., \& Wing, S. (2016). Urban-rural exploitation: an underappreciated dimension of environmental injustice. Journal of Rural Studies, 47, 350358. www.doi.org/10.1016/j.jrurstud.2016.03.010

Latour, B. (2004). Politics of nature. Cambridge, MS: Harvard University Press.

Latour, B. (2005). Reassemblying the social. Oxford: Oxford University Press.

Lino, C. F. (1992). Reserva da biosfera da Mata Atlântica: plano de ação. Campinas: UNICAMP. Lipton, M. (1979). Why poor people stay poor. London: Temple Smith.

Marston, S.A., Jones III, J.P., \& Woodward, K. (2005). Human geography without scale. Transactions of the Institute of British Geographers, 30, 416-432. www.doi.org/j.1475$\underline{5661.2005 .00180 . x}$

Marx, K. (1952). Capital. Chicago: Great Books.

Musumeci, L. (1987). Pequena produção e modernização da agricultura: o caso dos hortigranjeiros no estado do Rio de Janeiro. Rio de Janeiro: IPEA.

Merchant, C. (2004). Radical ecology. $2^{\text {nd }}$ Edition. London: Routledge.

MMA (Ministério de Meio Ambiente). (2016). Parna Pantanal. Retrieved from www.mma.gov.br/ estruturas/205/_arquivos/parna_pantanal_205.pdf

OECO (2008). Herdeiros da guerrilha pantaneira. Retrieved from www. oeco.org.br/reportagens/20205-herdeiros-da-guerrilha-pantaneira

Oliveira, A. (1999). A geografia das lutas no campo. São Paulo: Contexto.

Oliveira, R.R., Fraga, J. S., \& Berck, D.E. (2011). Uma floresta de vestígios: metabolismo social e a atividade de carvoeiros nos séculos XIX e XX no Rio de Janeiro, RJ. INTERthesis, 8, 286-315.

Page, B., \& Peet, R. (1994). Nature's metropolis: the ghost dance of Christaller and von Thunen. Antipode, 26, 152-162. 
Paulson, S., Gerzon, L.L., \& Watts, M. (2003). Locating the political in political ecology. Human Organization, 62, 205-217. www.doi.org/10.17730/humo.62.3.e5xcjnd6y8v09n6b

Peet, R., Robbins, P. \& Watts, M. (Eds.). (2011): Global political ecology. Milton Park: Routledge.

Peet, R.. \& Watts, M. (Eds.). (2004) [1996]. Liberation ecologies. London: Routledge.

Pepper, D. (1996). A history of environmental thought. London: Routledge.

Rickard, T.J. (2007). Rural sustainability issues for national parks. In T. Sorensen (Ed.), Progress in sustainable rural development (pp. 191-198). Cairns: IGU Commission on the Sustainability of Rural Systems.

Prefeitura da Cidade do Rio de Janeiro. (2012). Parque Natural Municipal da Serra do Mendanha: plano de manejo. Rio de Janeiro: FUNRIO/SMAC. Retrieved from www.rio.rj.gov.br/distatic/10112/5214698/4136049/2011_06PMCaracteriza_1.pdf

Redclift, M. (1987). Sustainable development. London: Methuen.

Robbins, P. (2003). Political ecology. Oxford: Blackwell.

Schmink, M., \& Wood, C.H. (1992). Contested frontiers in Amazonia. New York: Columbia Univ. Press.

Schwanen, T. (2018). Thinking complex interconnections: transition, nexus and Geography. Transactions of the Institute of British Geographers, 43, 262283. www.doi.org/10.1111/tran. 12223

Simmons, I.G. (1993). Interpreting nature. Cultural constructions of the environment. London: Routledge.

Simmons, I.G., \& Cox, N.J. (1985). Holistic and reductionistic approaches to geography. In R.J. Johnston (Ed.), The future of geography (pp. 43-58). London: Metheun.

SOS Mata Atlântica. (2015). SOS Mata Atlântica: história, parceiros e nossa causa. Retrieved from www.sosma.org.br

Taylor, M. (2015). The political ecology of climatic change adaptation. London: Routledge/Earthscan.

Vaz Filho, F.A. (2011). Povos indígenas no baixo Tapajós querem reconhecimento. In C.A. Ricardo \& F. Ricardo (Eds.), Povos indígenas do Brasil 2006/2010 (pp. 423-426). São Paulo: ISA. 
Whatmore, S. (2002). Hybrid ggeographies. London: Sage.

Wilson, A. (1992). The culture of nature. London: Routledge.

Wolf, E. (1966). Peasants. Englewood Cliffs: Prentice-Hall.

Wolf, E. (1982). Europe and the people without history. Berkeley: Univ. of California Press.

WWF (World Wildlife Fund) (2016). Áreas prioritárias para conservação da biodiversidade no cerrado e pantanal. Retrieved from www.wwf.org.br/natureza brasileira/reducao_de_impactos2/lep/lep_pub/?50162/reas-Prioritrias-para-conservao-dabiodiversidade-no-Cerrado-e-Pantanal

WWF (2018). Maior aumento de desmatamento da Amazônia em dez anos. Retrieved from www.wwf.org.br/?68662/ maior-aumento-desmatamento-amazonia-dez-anos\#

Zimmerer, K., \& Bassett, T.J. (Eds.). 2003. Political ecology: an integrative approach to geography and environment-development studies. New York: Guilford. 